\title{
Stakeholder Collaboration:
}

\author{
Networking Actor Collaboration in Handling Covid-19 the New Normal Era Indonesia
}

\author{
Klara Kumalasari*, Sujarwoto, I Gede Eko Putra Sri Sentanu \\ Department of Public Administration \\ University of Brawijaya \\ Malang, Indonesia \\ *klara.kumalasari1996@gmail.com, sujarwoto@ub.ac.id, sentanu@ub.ac.id
}

\begin{abstract}
The world is currently in a pandemic covid-19 that can be detrimental in various sectors including the government sector handling covid-19 has caused a policy governance crisis in various countries. The crisis of policy governance forces the government in to take policy seriously, this pandemic situation causes a policy crisis for it to need the cooperation of all actors and all elements of governance. Networking actor the componen that we need. This study aims to discuss the actor networking network in the handling of covid-19 judging by the classification of mapping the role of stakeholders in covid-19 handlers. This study uses a qualitative descriptive type. The focus of this research refers to mapping stakeholder roles that enable the networking of actors. The results of this study found that there are 5 (five) groups namely 1). The policy community. 2). Professional Network, 3). Network 4). Network producer 5) Network Issues put in. This research is expected to provide a complete picture of the actor networking collaboration network in the handling of covid-19 to lead to a new normal era as mentioned in the purpose of this study.
\end{abstract}

Keywords-stakeholder collaboration, networking actor, covid19, new normal

\section{INTRODUCTION}

By the end of 2019, the world will be hit by a pandemic of human-transmitted viruses that can kill and disrupt all sectors of the virus called covid-19 starting from Wuhan City in China, In March 2020 it was confirmed that there are 65 countries infected with the virus. As of January 24, 2020, at least 830 cases have been diagnosed with coronavirus in nine countries: China, Thailand, Japan, South Korea, Singapore, Vietnam, Taiwan, Nepal, and the United States [1].

The highest number of Covid-19 cases in 3 (three) Indonesian provinces in July. The first ranking of content by East Java was 17,829 positive cases and 1,338 cases of deaths and a $7.5 \%$ mortality presentation rate. Followed by DKI Jakarta in 2nd place, a total of 15,889 positive cases, 719 cases of death and a mortality percentage rate of $4.5 \%$. Lastly in south Sulawesi there were 7,713 positive cases, 268 deaths and a $3.5 \%$ mortality rate. East Java Province, the province with the highest mortality rate in Indonesia, showed that east Java province is among the most positive cases and the death rate of
COVID-19 in Indonesia is $8.9 \%$, the highest in Southeast Asia [2].

With the high number of covid-19 cases forcing the Indonesian government to issue various policies. First, establish an Accelerated Task Force (Satuan Gugus Tugas) on the handling of covid-19 with the legal basis based on presidential decree No.7year 2020 which is then amended to become the President's Decree No.9year 2020. One of the problems of this Task Force (Satuan Gugus Tugas) is to increase the security of national in the field of health, anticipate the escalation of the spread and increase readiness, the ability to prevent the spread of covid-19 and increase synergy between ministries or agencies and local governments in dealing with covid-19. The impact of the COVID-19 pandemic has been felt in many aspects of human life. Before the pandemic, people could live normally. Balance and comfort can be seen from various aspects, such as food availability, the availability of jobs, as well as the opportunity and flexibility to socialize or do mobility, as well as related to work affairs. However, the current pandemic situation clearly exacerbates the living conditions (balance) that we have been living and enjoying [3].

If we see the key of successful handling in Wuhan's from covid-19 citizen in china participation who follow the government's urge to stay at home until pandemic is done. The same is the case in South Korea which has been able to reduce the number of Covid-19 cases. The same was the case in New Zealand, where the New Zealand government implemented a lockdown policy after the first covid-19 case on March 23, a month after the country recorded its first case, New Zealand committed to a strict lockdown policy in all New Zealand regions. A few days later, Prime Minister Jacinda Ardern announced a strict national lockdown when it had only 102 cases and zero deaths Her rapid decision-making earned praise from the WHO (world health organization) [4]. The covid-19 global pandemic has caused new problems for nation-states, especially regarding how countries' efforts to prevent and stop the spread of it are not wide spread. Seeing the success of covid-19 handling in some of these countries Indonesia has been covid-19 to implement various policies such as Lockdown (closure of all access), PSBB (Social Restrictions at large) [5]. However, not all regions carry out such policies given 
Indonesia's decentralized state, which is that the central government gives its authority directly to the regions and regions it demands to be independent. Division of authority in the field of decision-making in lower-level organizations. That is, when decision-making is made only by a group of organizations including state organizations, it is considered centralization [6].

Thus the PSBB policy can be said to be a different step from the previous step which is just an exhorting asking the community to isolate themselves at home. With the policy of PSBB in offices, as a large industry and business people suffered economic losses [7]. According to Tri Rismaharini, The City Representative of Surabaya is (www.cnnindonesia.com) revealed that the reason for not implementing lockdown policy is that not all Surabaya people have monthly income but still many Surabaya people who earn only one day. If the lockdown is implemented the community economy in Surabaya will be affected but the mayor of Surabaya insists that one way to minimize the increase in positive numbers of covid-19 is to apply large-scale Social Restrictions

The government confirmed in regulation goverment No. 21 of 2020 that the Policy of Large-Scale Social Restrictions (PSBB) is established with consideration of the spread of Covid-19 with the number of cases or the number of deaths increasing and expanding across regions and across countries. In addition, the impact has resulted in a certain situation (Public Health Emergency) so that efforts are needed to be carried out, namely with PSBB action. Thus the PSBB policy can be said to be a different step from the previous step which is just an exhortment asking the community to isolate themselves at home. With the policy of PSBB in offices, as a large industry and business people suffered economic losses. Because the income of the community is decreasing and the urgency of the necessity of life, finally as the office and industry remain open, many people remain in the middle of this pandemic.

Government of East Java Province to mature and apply the concept of new normal era, broadly the concept of new normal era is to do normal activities in the midst of the pandemic. However, the positive number of covid-19 patients is still increasing in the new normal era as in the time lapse start form march until agust by tirta.id.

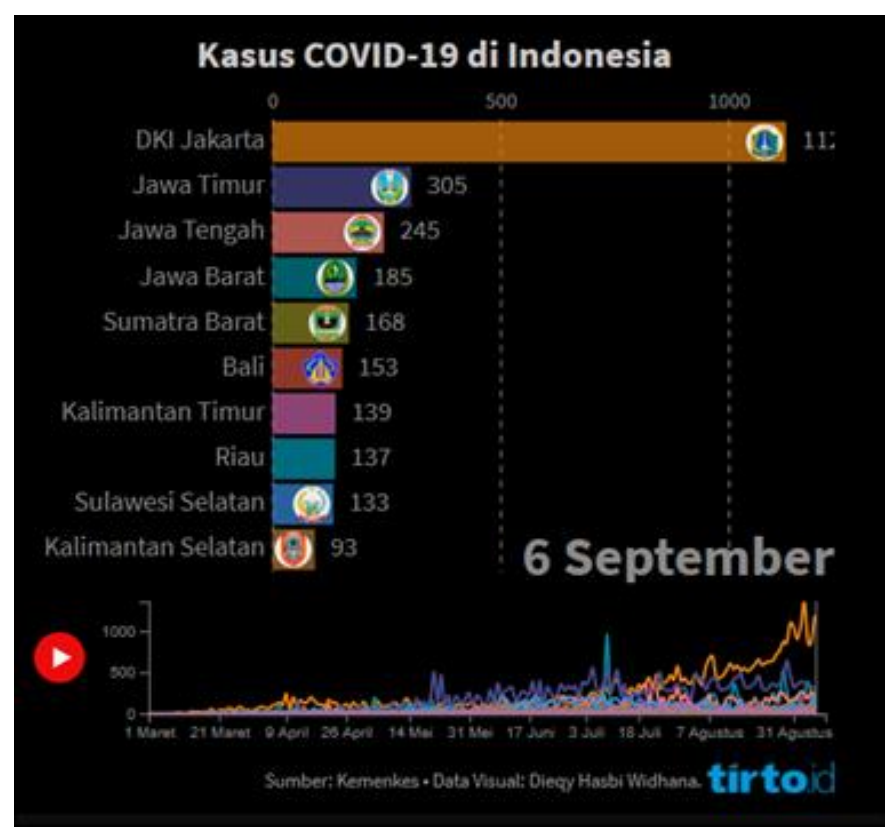

Fig. 1. Time lapse covid-19 in Indonesia Source: tirto.id.

The current pandemic is clearly exacerbating the living conditions (balance) that we have been living and enjoying. The covid-19 global pandemic has caused new problems for nation-states, especially regarding how countries' efforts to prevent and stop the spread of it are not widespread. The policy has made the health crisis worse and the number of medical personnel killed, the government is also required to create a post-pandemic recovery strategy. The number of issues that demand the government to make policy. When a country's prevention strategy succeeds in protecting itself from disease outbreaks it can be considered an effective strategy but if a country fails to protect against an outbreak then it can be considered an "ineffective strategy.

It should be the government to take the right policy targe there is a basis to make the policy necessary the cooperation of some actors and organizations that are competetion handling this case. Should the government no longer act as a single actor today) the government required to be able to build a network between actors in every public policy making. Strong cooperation will eliminate collaborative networking. Collaborative networking is a pattern of inherent relationships between related actors, the presence of strong cooperation, the presence of intense and widespread social relationships and capital. In the face of this pandemic the government must involve some competent actors in their field, even the public must also be involved in dealing with this outbreak. Thus the network of actors is very needed therefore this research will focus on the model of the actor network in covid-19 handlers in Indonesia. 


\section{LITERATURE}

\section{A. Pandemic Covid-19}

Pandemic is the constant presence of an infectious disease in a population within a given region, an epidemic is an increase in the number of cases of disease, often suddenly, above the normal limits predicted in a population in an area, whereas pandemics are epidemics that have spread to several countries and continents with massive amounts of transmission. Similarly, Covid-19 is a virus that can attack the respiratory system with symptoms of fever, cough, colds, sore throat, shortness of breath, fatigue, and lethargy. In severe cases it can cause pneumonia, acute respiratory syndrome, to death [8].

According to virologists from China, Covid-19 is classified as a new type of coronavirus and is different from the virus that causes SARS. The incubation period is about 7-14 days. Covid-19 spreads by air and in direct contact with sufferers (Kompas, 23 January 2020). On February 11, 2020, the World Health Organization named the new virus Severe acute respiratory syndrome coronavirus-12 (Sars-CoV-2). And the name of the disease as Coronavirus disease 2019 (covid-19). Respiratory infections caused by Covid-19 first appeared in Wuhan, China in early December 2019. The first case allegedly related to Wuhan city's animal and seafood market. This indicates the transmission from animals to humans.

\section{B. Networking Actor}

Networking has become a key concept of public policymaking. The same goes for the research community involved in analyzing and evaluating policymaking and results. As a result, there is an organizational mismatch between the government issues that must be resolved and the associated organizational structure assigned to address this issue. In addition, among policymakers, a network of collaboration is an important strategy, necessary to realize the goals of various policy programs [9]. Networks that appear in relation to the shared problemsolving process sometimes, as shown above, the result of deliberate strategy and political decision-making. At other times, however, the network has its own more organized character, with no formal connection to government agencies or formal policy programs. Either way, social issues are often addressed in this essentially boundary structure involving participants from different levels as well as from different organizational units [10].

\section{RESEARCH METHODS}

\section{A. Types of Research}

The approach used in this study is qualitative research with a type of qualitative descriptive research. By describing collaborative phenomena between stakeholders, the role of organizations (communities) and communities in the development of covid-19 cases. In the course of inadequate materials and research, the authors will describe the results of the study through several valid sources and draw conclusions from several articles and journals that correspond to the researcher's title.

\section{B. Data Source}

The data sources in this study use secondary data sources, secondary data is a support obtained from sources relevant to the topic of covid-19, usually in the form of document retrieval, reports or data, as well as other materials and information supporting in research.

\section{RESULTS AND DISCUSSION}

This covid-19 pandemic handler requires the government to be more assertive in its policy making to collaborate with various sectors. Basically no policy works if it only uses 1 actor. Therefore, it is appropriate in government policy making involving actors or experts. By engaging with many experts/actors will result in an inherent pattern between actors, many of the actor networking involved will automatically conciliation better ideas or ideas and creativity. As Indonesia did in handling covid-19, the Indonesian government established a TASK FORCE specifically to deal with covid-19, the task force to accelerate the covid-19 conversion is below and accountable to the President.

According to Presidential Decree No. 7 of 2020 article 3 mentions the task force to accelerate the implementation of covid-19aims to:

- Improving national security in the field of health

- Improving anticipation of the escalation of covid-19 spread

- To increase policy-added synergies and

- Improving readiness in preventing, detecting and responding to covid- 19 .

The task force on covid-19 is composed of a). Director : both dissized instructions where in the perceived perceptan handling of covid-19 and and follow the instructions and instructions of accelerating the implementation of covid-19. b). The implementer also coordinates and exercises the acceleration of covid-19 handler activities, supervision and reports of covid-19 impeachment of the president and director. In the document of the covid-19 pandemic protocol, efforts to accelerate covid-19 in several sectors such as government, private, public, and media. 


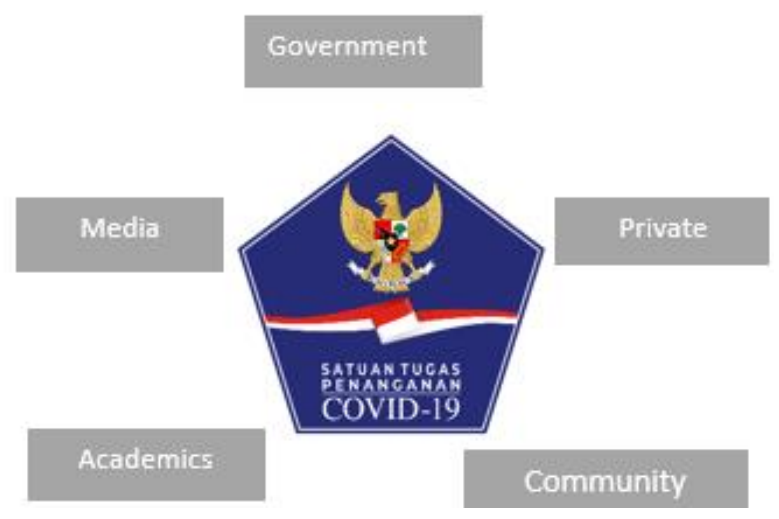

Fig. 2. The involvement of several sectors in handling covid-19. Source: document protocol confectionary covid-19.

By engaging several sectors from non-governmental circles, the government's efforts to increase resources that can be moved into opportunities and overcome a number of challenges in the field. If we look at theory the network is based on the assumption that the relaxation of the actors is entered dependent on each other. This means that actors are not able to achieve their goals without using the resources that other actors have, one characteristic of network theory is the connection of both the lowest level, or higher level. The study also revealed the relationship between policy actors in covid19.

The network is divided into 5 (five) groups namely 1). The policy community comprises the National People's Congress. 2). Professional network consisting of scholars, colleges and research institutes, 3). The intergovernmental network consists of governments at all levels interacting with each other, 4). Producer network consisting of interest groups, 5). Issue Network puts in the outermost layer of network policy due to loose structure, many members, low level system and informal decision-making way a member in network issues [11].

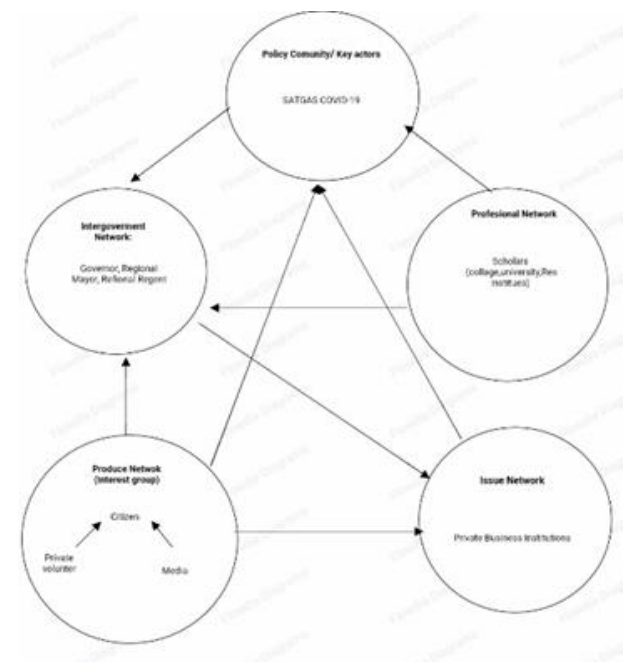

Fig. 3. Interactive relationships of policy network actor in Indonesia. Source: By researcher (2020).
Please note that the relationship between actors and each other is synergistic such as Policy Community or key actors who are at the coordination center of covid-19handlers. In this case, the government chose the Covid-19 Acceleration Task Force as the institution responsible for the covid-19 in Indonesia, mean while the Inter Goverment Network consists of local governments that monitor their regions.

There is a professional network in network theory consisting of researchers ranging from universities and research institutions responsible to the Ministry of Education (policy community). Various studies and modeling related to covid-19 were also launched as a foothold in policy making.

Furthermore, produce network group consisting of community and media. The community is the most important resource in covid-19. Various forms of contributions and initiatives that appear in the community become capital as part of covid-19 development forms including community-based activities volunteer communities. In addition to the produce network community also consists of media that is an important platform in the delivery of information both offline and online, media also helps contribute means of communication to the community and conveys the compliance of covid-19.

The last is an Issue network consisting of private business institution. The impact of the access restriction policy in the covid-19 ban was felt by the swast which required a temporary halt to some economic activity. Therefore, the trustees involve business or private institutions to build cooperation with business institutions that have a commitment to provide good support in the development. Human resources, asset lending or tang business infrastructure are owned. Then the last one is issue network consisting of media. Media is a platform of information delivery both offline and online. By engaging many resource sectors in the covid-19 deed is sufficient.

\section{CONCLUSION}

The paper primarily studies the issue of networking actors based on policy network theory. It turns out that government is the most powerful coordination In general, policy network theory can find out who has strong authority. It is supposed to be in determining policy networks as well as coordinating public and private interests, this can increase efficiency in the implementation of public policy because the government organizations are no longer central steering actors in the policy process. So that the roles of all actors can be maximized.

\section{REFERENCES}

[1] S.S. Unhale, Q.B. Ansar, S. Sanap, S. Thakhre, S. Wadatkar, R. Bairagi, ... and K.R. Biyani, "A review on corona virus (COVID-19)," World Journal of Pharmaceutical and life sciences, vol. 6, no. (4), pp. 109-115, 2020 .

[2] A. Susilo, C.M. Rumende, C.W. Pitoyo, W.D. Santoso, M. Yulianti, H. Herikurniawan, ... and E. Yunihastuti, "Coronavirus disease 2019: Tinjauan literatur terkini," Jurnal Penyakit Dalam Indonesia, vol. 7, no. (1), pp. 45-67, 2020 
[3] D.R. Buana, "Analisis perilaku masyarakat indonesia dalam menghadapi pandemi virus corona (Covid-19) dan kiat menjaga kesejahteraan jiwa," Salam: Jurnal Sosial dan Budaya Syar-i, vol. 7, no. (3), pp. 217-226, 2020.

[4] S. Cousins, "New zealand eliminates covid-19," The Lancet, vol. 395, no. (10235), p. 1474, 2020.

[5] R.L. Daft, Organization theory and design. Boston, US: Cengage learning, 2015.

[6] P. Simatupang and H. Akib, "Efektivitas Implementasi dan Dampak Kebijakan dalam Konteks Desentralisasi Pemerintahan," Jurnal Ilmiah Ilmu Administrasi Publik, vol. 2, no. (1), pp. 1-9, 2011.

[7] P.J. Hairi, "Implikasi Hukum Pembatasan Sosial Berskala Besar Terkait Pencegahan Covid-19," Bidang Hukum Info Singkat, vol. 12, no. (7), pp. 1-6, 2020.
[8] Lisbet, "Penyebaran covid-19 dan respon Internasional," Pusat Penelitian Badan Keahlian DPR RI, no. (9), p. 7, 2020.

[9] P. Bogason and T.A. Toonen, "Introduction: Networks in public administration," Public Administration, vol. 76, no. (2), pp. 205-27, 1998.

[10] L.J. O'Toole Jr, "Research on policy implementation: Assessment and prospects," Journal of public administration research and theory, vol. 10, no. (2), pp. 263-88, 2000.

[11] N. Zhou, X. Xiao, and F. Feng, "Citizen Participation in the Public Policy Process in China: Based on Policy Network Theory," Public Administration Research, vol. 3, no. (2), p. 91, 2014. 